\title{
OBSERVATIONS ON THE ANTI-INFECTIOUS POWER OF THE BLOOD OF INFANTS.*
}

\author{
RUTH TUNNICLIFF.
}

(From the Memorial Institute for Infectious Diseases, Chicago.)

VARIous observers have compared the antibodies in the blood serum of the newborn with those in adult serum. Halban and Landsteiner ${ }^{x}$ found that mother's blood possessed more hemolysins, agglutinins, bactericidins, antiferments, antitoxins, and precipitins than the blood of the fetus at birth. Wright and Douglas ${ }^{2}$ found that the opsonic power of the serum of two infants at birth toward staphylococci equaled that of the mother. Wells ${ }^{3}$ studied the opsonins of a large number of infants under one year old. Wells and Freeman made observations of the opsonic indices of the sera of parturient women and their newborn babies. The samples of the blood of the newly born infants were taken from the umbilical cord. The average opsonic indices of the blood of $\mathbf{I} 7$ babies as compared with those of I I mothers were 0.8 to the tubercle bacillus, I.I8 to the staphylococcus, I.4 to the streptococcus, and 0.39 to the colon bacillus. Pooling the sera of children from $1-4$ weeks old and comparing their phagocytic index with that cf the pooled sera of healthy men, Wells found that the opsonic indices to the tubercle bacillus, staphylococcus, streptococcus, and colon bacillus dropped considerably after birth. From the examination of individual samples of infant blood he found a rise in the opsonins later on and that the opsonic indices were subject to great fluctuations from time to time. He draws the following conclusions:

1. A low opsonic index is not diagnostic in children under one year old.

2. In infants a low opsonic index is not inconsistent with health, and the child may be thriving well with a declining index.

3. Where the opsonic index is low this will rise in response to the stimulus of an inoculation with a bacterial vaccine.

4. Results would appear to show that the healthy breast-fed infant possesses no advantages over the healthy artificially fed child.

5. The anti-bacterial defense in children cannot depend upon the opsonic content of the serum.

Amberg's 4 results using staphylococcus bear out those of Wells in regard to the drop in opsonic power after birth and the rise later on. Amberg found an increased opsonic power in the breast-fed infant, but considered it dependent to some extent on the state of nutrition of the infant and on its constitution.

Turton and Appleton 5 found in two 7 - and 4 -days-old babies that the opsonic power of their blood to the tubercle bacillus was much less than that of the mother's as compared with normal serum. They examined the staphylococcus opsonic index

* Received for publication May ro, rgro.

I Münch. med. Wchnschr., 1902, 49, p. 473.

- Proc. Roy. Soc, B., 1904, 74, p. 147.

4 Jour. Amer. Med. Assoc., r907, 48, p. 304.

3 Practitioner, I908, 80, p. 635 .

3 Brit. Med. Jour., 1907, 13, p. 865. 
of the 7 -days-old infant and found it also below normal. Much observed that the staphylococcus and streptococcus opsonic index of the newborn was the same or only slightly less than that of adult serum.

Eisler and Sohma ${ }^{2}$ studied the opsonic power of guinea-pigs toward staphylococci and of rabbits toward streptococci. They found that the blood serum of newborn animals possessed the same opsonic power as that of the normal mother. The opsonin appeared in the fetus during the last third of pregnancy. They did not find any transmission of immune opsonins from mother to child.

Flamini3 studied the opsonic index in 26 normal infants, using rabbit leukocytes and the colon bacillus. The youngest babies examined by him were three days old. At this time he found that the opsonic power of the serum failed altogether or was small in amount as compared with normal adult serum and that it was not as great as adult serum even at the second year. He observed that the amount of opsonin varied with the weight of the child and was lower in artificially fed infants than in breast-fed.

Cathala and Lequeux 4 found that the staphylococcus opsonic index of the blood from the umbilical cord was perhaps a little lower than that of adult blood and diminished slightly during the first days of life.

No one appears yet to have studied the phagocytic power of infant leukocytes. As it has been shown that the phagocytic power of the leukocytes in health and disease varies quite as much as the opsonic power of the serum, I undertook to study the phagocytic power of the leukocytes as well as the opsonic power of the serum in normal infants.

These experiments concern healthy institutional children who had not been suffering from recent acute infections. Of those under one year all were breast-fed except two (one six weeks and the other four months old). On account of the small number of children examined, no light has been thrown on the influence of nutrition on the phagocytic power of the blood in infancy.

In order to compare the activity of adult and infant leukocytes, suspensions containing the same number of polymorphonuclear leukocytes were used. The washed leukocytes were standardized by counting the number of polymorphonuclear leukocytes in a given volume of each suspension by means of a white-blood counting apparatus. The leukocytic suspensions were then equalized by the necessary amount of normal salt solution.

Normal adult serum and leukocytes were used as the control. The control and infant blood were collected and kept under the

s Müch. med. Wchnschr., 1908, 55, p. 572.

,Wion. klin. Wchnschr., 1908, 21, p. 684 .
3 Rivista di Chir. Pediat, I908, 6, p. 572.

4 L'Obstetrique, 1909, 14, p. 393. 
same conditions as nearly as possible. The blood at birth was taken from the umbilical cord.

The bacteria employed in the experiments were streptococci, pneumococci, and staphylococci. The streptococcus was a typical Strept. pyogenes made virulent by passage through rabbits. The pneumococcus had been isolated from the blood of a pneumonia patient. The staphylococcus was a Staph. aureus isolated from a furuncle in a patient suffering from chronic furunculosis.

Mixtures containing equal volumes of serum, standardized leukocytes, and bacterial suspension were prepared in the usual way for determining the opsonic index. Mixtures were made of adult serum with both adult and infant leukocytes, and infant serum with both adult and infant leukocytes. From these four suspensions one can determine the influence on phagocytosis of (I) the infant's serum (opsonic index); (2) the infant's leukocytes (the cytophagic index of Glynn and Cox); and (3) the influence of the serum and leukocytes combined (the opsono-cytophagic index of Glynn and Cox ${ }^{\mathrm{x}}$ ).

The opsonic index is obtained with both adult and infant leukocytes. The phagocytic activity of the leukocytes is estimated by comparing mixtures of one serum (adult or infant) and adult leukocytes with the same serum and infant leukocytes. The total phagocytic power of the blood is determined by comparing mixtures of adult serum and leukocytes with infant serum and leukocytes. This index undoubtedly gives a more accurate estimation of the phagocytic power of the blood than the opsonic index, because it includes both the opsonic power of the serum and the phagocytic power of the leukocytes. To obtain this index it is necessary to use washed standardized leukocytes. Using the whole citrated blood as suggested by Vietch ${ }^{2}$ and others does not give the same results unless both specimens of blood contain about the same number of polymorphonuclear leukocytes.

\footnotetext{
1 Jour. of Path. and Bact., I909, 14, p. go. Glynn and Cox use the term cytophagic (an inversion of phagocytic) index to express the inherent phagocytic capacity of the leukocytes alone. They express the result of comparing the combined action of leukocytes plus serum of two persons by the term opsonocytophagic index. This index gives the total phagocytic power of any blood. It corresponds to the "hemophagocytic" index of Shattock and Dugeon (Proc. Roy. Soc., B., 1907, 80, p. 165), and the "opsono-phagocytic" index of Nikolsky. Nikolsky (Centralbl. f. Bact., I, Orig., 19 ro, 53, p. 544) uses the term phagocytic coefficient instead of phagocytic index as usually cmployed to indicate the number of bacteria engulfed by the leukocytes of one person alone. He uses phagocytic index to denote the inherent phagocytic power of the leukocytes.

- Jour. of. Path and Bact., 1908, 12, p. 353.
} 
In two infants with diminished phagocytic power, counts were made to determine the variations in the number of cells belonging to the different classes of Arneth and their respective phagocytic power. No differences could be found between the adult and infant leukocytes so studied.

In the tables the indices are determined by estimating the number of bacteria ingested per leukocyte. Equivalent results are obtained by comparisons of the number of cells taking part in phagocytosis in the various mixtures.

Table I shows the opsonic indices of infant serum, using both adult and infant leukocytes. It indicates that the opsonic indices are about the same whether adult or infant leukocytes are employed.

Table 2 shows first the phagocytic activity of infant leukocytes (cytophagic index) using first adult serum and leukocytes and then infant serum and leukocytes as unity. The results are very similar whichever combination is used. The figures at the right end of Table 2 show the phagocytic power of the whole blood by comparing infant serum and infant leukocytes with adult serum and adult leukocytes (opsono-cytophagic index).

On finding that the serum of several infants at birth had the same amount of opsonin as adult serum and that the leukocytes also were as active as adult, while the infants examined after birth showed less opsonin and less phagocytic activity, the blood of two infants (marked (r) and (2) in the tables) was examined several times. The tables show that both the opsonin and the phagocytic power of the leukocytes in the two infants so examined decreased considerably a few days after birth.

The mothers of the children whose blood was examined at birth were apparently normal. Nothing in the previous history of the mothers of the first, second, and fifth babies in the tables could account for the differences between their blood and that of adult.

The blood of seven children who had recovered from various acute infections was examined. One seven-months-old baby who had just had an acute attack of enteritis had low opsonic indices to streptococci and staphylococci, being almost the same as those of a normal child of that age. The pneumococcus index in this child was normal. The leukocytes had less phagocytic power than the adult with 
respect to all these organisms but somewhat greater than the leukocytes of a normal child of the same age. The other six infants had recovered from gonorrhea. These children, some in a bad state of nutrition, had opsonic indices which were quite as high as, sometimes higher than, those of infants of the same age who were apparently normal. The phagocytic power of thcir leukocytes also compared favorably with that of normal infants. Two children, two years old, who had recovered from gonorrhea had the same amount of opsonin as adult serum. One of these children had also recovered from diphtheria, and scarlet fever complicated with otitis media. Her leukocytes possessed the same phagocytic power as adult.

The seven- and eighteen-months-old normal infants had high opsonic indices to the pneumococcus both with adult and with their own leukocytes. Both children were from the same institution and were considered normal. The high pneumococcus indices indicate that they were unquestionably recovering from some pneumococcus infection and are therefore not included in the charts showing the opsono-cytophagic indices.

TABLE I.

The Opsontc Index of Infants' Serum for Streptococcus, Panumococcus, and Staphylococcus.

\begin{tabular}{|c|c|c|c|c|c|c|c|c|}
\hline \multirow{2}{*}{ AgE } & \multirow{2}{*}{ SEX } & \multicolumn{3}{|c|}{$\begin{array}{l}\text { Opsonic INDEx or NoRMal } \\
\text { INFANTS' SER UM USING } \\
\text { NORMAL ADULT LEUKOCYTES }\end{array}$} & \multicolumn{4}{|c|}{$\begin{array}{l}\text { OrSONIC INDEX OF NoRmal INFANTS' } \\
\text { SERUM USING NoRMaL INFANTS' } \\
\text { LEUKOCYTES }\end{array}$} \\
\hline & & $\begin{array}{l}\text { Strepto- } \\
\text { coccus }\end{array}$ & $\begin{array}{l}\text { Pneumo- } \\
\text { coccus }\end{array}$ & $\begin{array}{l}\text { Staphylo- } \\
\text { coccus }\end{array}$ & $\begin{array}{l}\text { Strepto- } \\
\text { coccus }\end{array}$ & $\begin{array}{l}\text { Pneumo- } \\
\text { coccus }\end{array}$ & $\begin{array}{l}\text { Staphylo- } \\
\text { coccus }\end{array}$ & $\begin{array}{l}\text { Age of } \\
\text { Infants' } \\
\text { Leukocytes }\end{array}$ \\
\hline 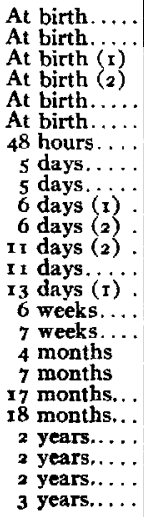 & $\begin{array}{l}\mathbf{B} \\
\mathbf{B} \\
\mathbf{B} \\
\mathbf{B} \\
\mathbf{B} \\
\mathbf{B} \\
\mathbf{B} \\
\mathbf{G} \\
\mathbf{G} \\
\mathbf{B} \\
\mathbf{B} \\
\mathbf{B} \\
\mathbf{B} \\
\mathbf{B} \\
\mathbf{B} \\
\mathbf{B} \\
\mathbf{B} \\
\mathbf{B} \\
\mathbf{B} \\
\mathbf{B} \\
\mathbf{G} \\
\mathbf{B} \\
\mathbf{G} \\
\mathbf{G}\end{array}$ & $\begin{array}{l}0.4 \\
0.6 \\
0.79 \\
0.77 \\
0.007 \\
0.4 \\
0.37 \\
0.94 \\
0.91 \\
1.1 \\
0.3 \\
0.26 \\
0.64 \\
0.46 \\
0.6 \\
0.3 \\
0.8 \\
0.5 \\
0.6 \\
0.7 \\
0.9 \\
1.2 \\
0.89 \\
1.0\end{array}$ & $\begin{array}{l}1.1 \\
0.67 \\
1.2 \\
1.3 \\
0.05 \\
0.02 \\
0.57 \\
0.05 \\
0.08 \\
0.39 \\
0.5 \\
0.5 \\
0.16 \\
0.5 \\
1 . .5 \\
0.0019 \\
0.3 \\
3.0 \\
0.8 \\
1.4 \\
1.0 \\
0.63 \\
1.0 \\
1.0\end{array}$ & $\begin{array}{l}0.88 \\
0.29 \\
0.96 \\
0.8 \\
0.7 \\
0.4 \\
0.4 \\
0.3 \\
0.4 \\
0.6 \\
0.19 \\
0.66 \\
0.8 \\
0.24 \\
0.6 \\
0.47 \\
0.69 \\
0.14 \\
0.25 \\
0.22 . \\
0.7 \\
0.6 \\
0.9 \\
1.0\end{array}$ & $\begin{array}{l}1.4 \\
0.9 \\
0.9 \\
0.99 \\
0.3 \\
0.3 \\
0.3 \\
0.9 \\
1.3 \\
1.6 \\
0.32 \\
0.7 \\
\cdots . .1 \\
0.17 \\
\cdots 0.01 \\
0.5 \\
0.12 \\
0.6 \\
0.4 \\
0.75 \\
0.76 \\
\cdots .7 \\
0.72\end{array}$ & $\begin{array}{l}1.0 \\
0.6 \\
1.2 \\
1.2 \\
0.5 \\
0.01 \\
0.5 \\
0.6 \\
0.8 \\
0.5 \\
0.7 \\
0.7 \\
0 . . \\
1.0 \\
\ldots .0 \\
0.03 \\
0.6 \\
17.0 \\
0.36 \\
1.6 \\
0.9 \\
0.8 \\
\ldots .8 \\
0.8\end{array}$ & $\begin{array}{l}0.9 \\
0.8 \\
1.3 \\
1.1 \\
1.0 \\
0.3 \\
0.8 \\
1.0 \\
\ldots . . \\
0.4 \\
0.7 \\
\cdots . . \\
0.1 \\
0.1 \\
0.0 \\
0.004 \\
0.7 \\
0.09 \\
0.2 \\
0.4 \\
0.32 \\
0.65 \\
0.8\end{array}$ & 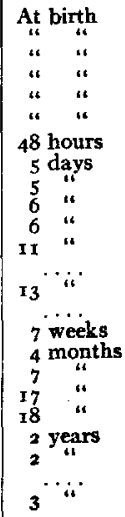 \\
\hline
\end{tabular}


Anti-infectious Power of Blood of Infants 703

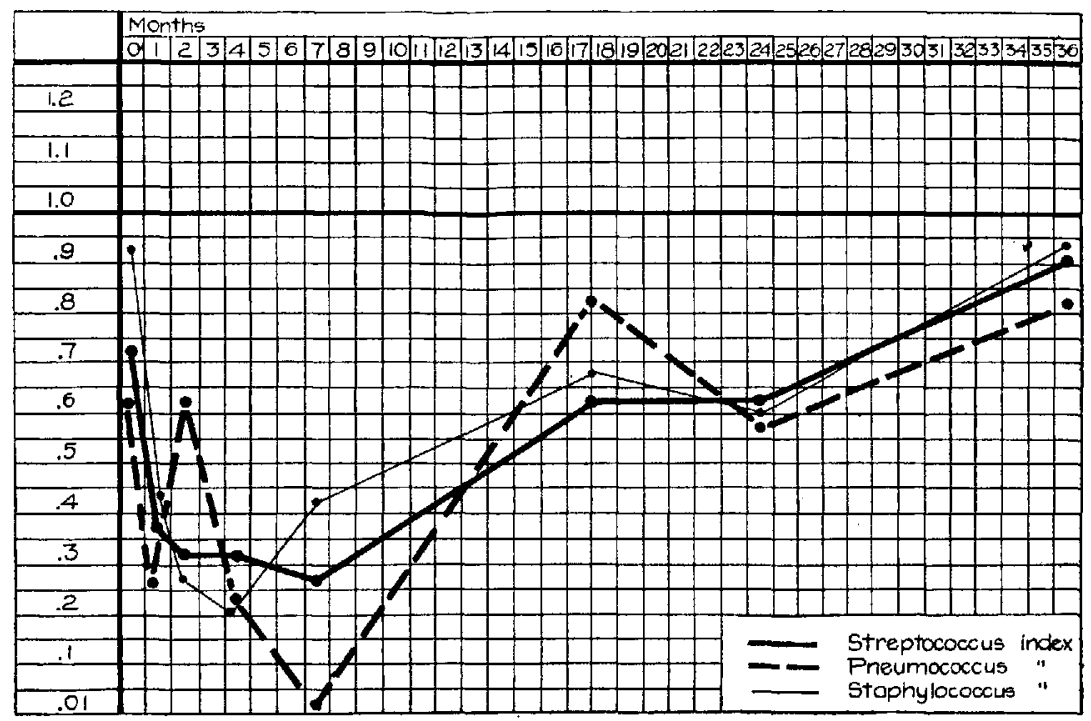

CHART T.-The phagocytic power of infant leukocytes compared with that of adult leukocytes under the influence of adult serum (cytophagic index).

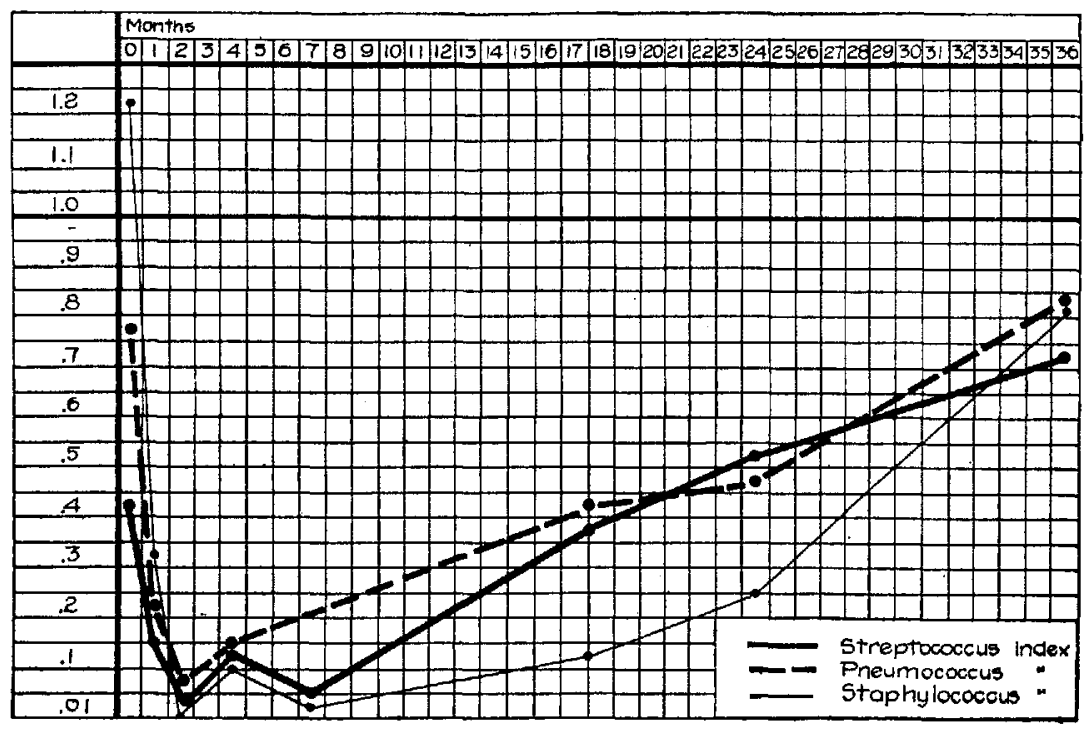

Chart 2.- The phagocytic power of infant serum and infant leukacytes compared with the phagocytic power of adult serum and adult leukocytes (opsono-cytophagic index). 


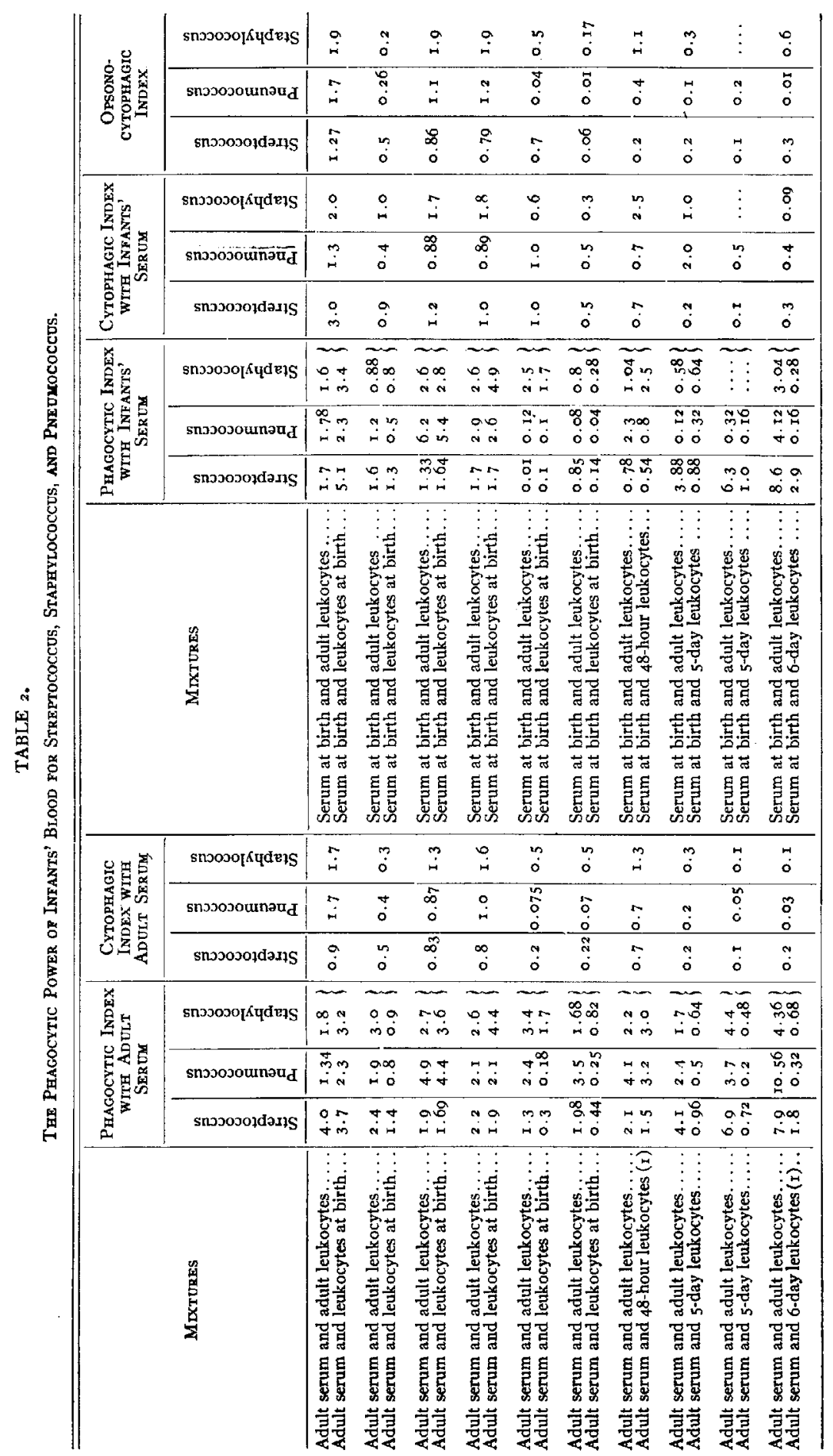




\begin{tabular}{|c|c|c|c|c|c|c|c|c|c|c|c|}
\hline$\stackrel{T}{0}$ & $\vdots$ & 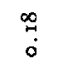 & $\begin{array}{l}8 \\
0 \\
0\end{array}$ & $\stackrel{\overrightarrow{0}}{\stackrel{0}{0}}$ & $\begin{array}{l}\overrightarrow{0} \\
\stackrel{0}{0} \\
0\end{array}$ & $\begin{array}{c}\pi \\
0 \\
0\end{array}$ & $\begin{array}{l}8 \\
\stackrel{0}{0}\end{array}$ & & $\stackrel{\leftrightarrow}{\circ}$ & $\stackrel{m}{0}$ & $\stackrel{\infty}{0}$ \\
\hline $\begin{array}{l}\text { i̊ } \\
\stackrel{0}{0} \\
0\end{array}$ & $\stackrel{m}{0}$ & $\begin{array}{l}? \\
? \\
0\end{array}$ & $\begin{array}{l}\overrightarrow{0} \\
0 \\
0\end{array}$ & $\ddot{0}$ & $\begin{array}{l}\text { मे } \\
\text { के }\end{array}$ & $\stackrel{+}{\circ}$ & $\stackrel{\rho}{\dot{0}}$ & & $\begin{array}{l} \\
\\
0\end{array}$ & m & $\stackrel{\infty}{0}$ \\
\hline $\begin{array}{l}8 \\
0 \\
0\end{array}$ & $\stackrel{3}{0}$ & $\stackrel{m}{0}$ & $\begin{array}{l}\overrightarrow{8} \\
\stackrel{0}{0}\end{array}$ & : & ọ & $\ddot{0}$ & 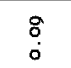 & & $\dddot{n}$ & $\stackrel{n}{0}$ & $\stackrel{乛}{0}$ \\
\hline 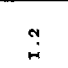 & $\vdots$ & $\begin{array}{l}5 \\
0 \\
0\end{array}$ & $\begin{array}{l}\bar{g} \\
\dot{g} \\
0\end{array}$ & $\stackrel{9}{0}$ & $\ddot{m}$ & $\stackrel{\circ}{\circ}$ & $\tilde{0}$ & & $\stackrel{m}{0}$ & $\ddot{n}$ & $\stackrel{\infty}{\infty}$ \\
\hline$\stackrel{n}{0}$ & $\ddot{0}$ & $\ddot{0}$ & $\stackrel{\circ}{\sim}$ & $\stackrel{N}{\circ}$ & $\stackrel{N}{0}$ & $\stackrel{T}{0}$ & $\begin{array}{c}\infty \\
0 \\
0\end{array}$ & & $\stackrel{+}{0}$ & $\stackrel{\infty}{\circ}$ & 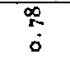 \\
\hline$\stackrel{4}{0}$ & $\stackrel{t}{i}$ & $\stackrel{m}{0}$ & $\begin{array}{l}\overrightarrow{8} \\
\stackrel{0}{0}\end{array}$ & $\stackrel{\text { ơ }}{\circ}$ & $\stackrel{n}{0}$ & $\stackrel{9}{ت}$ & $\stackrel{\circ}{-}$ & & $\stackrel{a}{0}$ & $\stackrel{+}{0}$ & $\begin{array}{l}a \\
\vdots \\
0\end{array}$ \\
\hline $\begin{array}{l}\pi 0 \\
00 \\
00\end{array}$ & $\approx:$ & $\widetilde{\sim}$ & $\begin{array}{l}\text { तo } \\
0 \\
0 \\
0\end{array}$ & भुष & 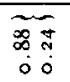 & ד্ & 总品 & & $\begin{array}{l}\sim \widetilde{\alpha} \\
0 \% \\
\text { mo }\end{array}$ & $\tilde{N}=m$ & $\overline{n i m}$ \\
\hline$\stackrel{0}{0} \underset{0}{m}$ & $\begin{array}{l}\dot{O}_{\infty}^{\infty} \\
\dot{i n}\end{array}$ & $\stackrel{90}{\dot{m}}$ & $\begin{array}{l}80 \\
0 \% \\
00\end{array}$ & 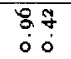 & के & $\begin{array}{l}\infty \\
0 \\
0\end{array}$ & $\stackrel{\circ}{9}$ & & 웅 & 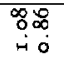 & 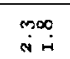 \\
\hline तू & â & 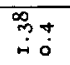 & 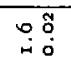 & $\begin{array}{l}00 \\
\dot{m}\end{array}$ & 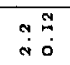 & 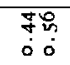 & 우 & & 象 & 苗 & : \\
\hline 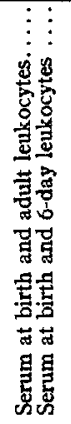 & 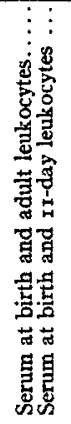 & 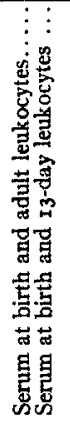 & 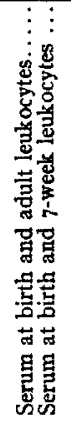 & 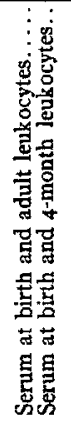 & 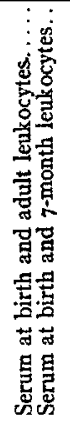 & 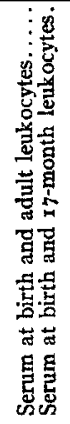 & 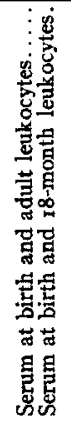 & 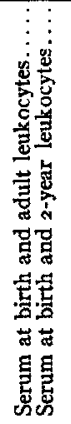 & 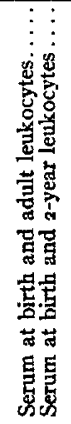 & 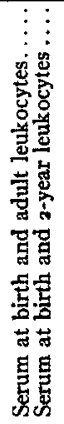 & 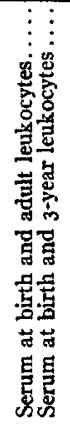 \\
\hline$\stackrel{m}{0}$ & $\ddot{0}$ & $\begin{array}{l}2 \\
0 \\
0\end{array}$ & !n & $\stackrel{*}{0}$ & $\stackrel{+}{\dot{0}}$ & $\stackrel{\sim}{4}$ & 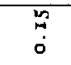 & $\ddot{0}$ & $\hat{0}$ & $\begin{array}{l}7 \\
0\end{array}$ & $\stackrel{\infty}{\circ}$ \\
\hline$\stackrel{m}{0}$ & पे & $\ddot{0}$ & $\stackrel{0}{\circ}$ & : & $\begin{array}{l}0 \\
\stackrel{0}{0} \\
\dot{0}\end{array}$ & 3 & $\ddot{0}$ & & $\stackrel{+}{\dot{0}}$ & $\stackrel{\circ}{\circ}$ & $\stackrel{\infty}{0}$ \\
\hline$\stackrel{H}{\circ}$ & $\ddot{0}$ & 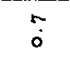 & $\vec{o}$ & ? & "ָ̀ & $\stackrel{\circ}{\longrightarrow}$ & $\tilde{O}$ & $\begin{array}{l}5 \\
0 \\
0\end{array}$ & $\dot{0}$ & $\stackrel{0}{\circ}$ & $\begin{array}{c}\infty \\
\infty \\
0 \\
0\end{array}$ \\
\hline 禹 & $\widetilde{0}$ & $\overbrace{\infty}^{\infty}$ & $\overline{0}$ & $\widetilde{m}$ & 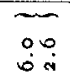 & $\begin{array}{l}\widetilde{S} \\
\dot{S}\end{array}$ & $\widetilde{a}$ & $\vec{a}$ & 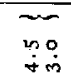 & $\widetilde{\sim}$ & ind \\
\hline 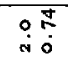 & $\stackrel{+\infty}{\infty}$ & 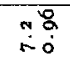 & 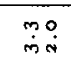 & Mo & 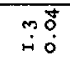 & $\begin{array}{l}P_{\infty}^{\infty} \\
\vdots 0 \\
00\end{array}$ & 98 & ته & $\begin{array}{l}+\infty \\
-\infty\end{array}$ & 喵 & ن \\
\hline 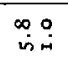 & $\stackrel{\infty}{\infty}+\dot{q}$ & $\ddot{m}$ & $\begin{array}{l}n \circ 0 \\
\dot{y}\end{array}$ & $\stackrel{+H}{\dot{m}}$ & $\infty^{\infty} 0$ & $\begin{array}{l}10 \\
0 \\
00\end{array}$ & mo & نَّ & $\stackrel{H}{i}$ & 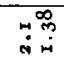 & $\underset{\sim i n}{+0}$ \\
\hline 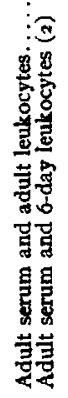 & 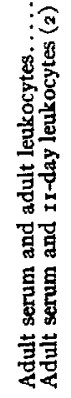 & 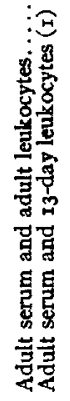 & 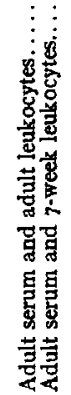 & 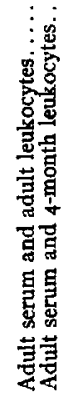 & 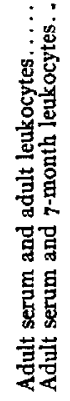 & 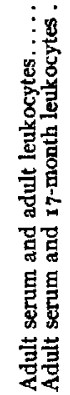 & 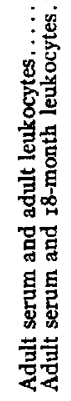 & 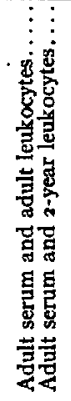 & 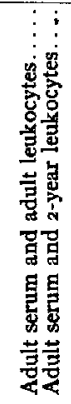 & 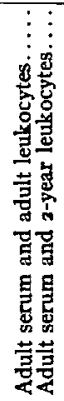 & 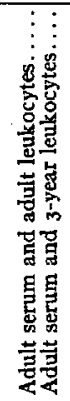 \\
\hline
\end{tabular}


The tables show considerable variation in the opsonic power of the serum and the leukocytic activity of infants of the same age. The charts are made from the averages of all the estimations for one age compared with adult leukocytes and serum.

Referring to the conclusion of Wells that low opsonic indices in children are not diagnostic, I would point out that to determine the opsonic index in infants their serum must be compared with that of healthy infants of the same age and not with that of adults. On account of the low opsonic indices in infants, Wells concludes. that the antibacterial defense in children cannot depend upon the opsonic content of the serum. He does not seem justified in this conclusion in view of the fact that babies are so highly susceptible and show so little resistance to bacterial infections.

According to Holt, ${ }^{\mathbf{2}} 20-25$ per cent of all deaths are of infants under one year; 55.I per cent of the deaths at this time are caused by bacterial diseases. Holt shows that 25 per cent of the deaths of infants under one year occur during the first month of life, the death rate then gradually decreasing. My results, as seen from Chart 2, are in accord with these statistics, showing that during the first months of life when the death rate is highest the anti-infectious power of the blood is lowest.

It is unwarranted to draw definite conclusions from the small number of infants examined, but the results of my experiments would indicate:

I. That at birth the opsonic power of the blood serum toward streptococci, pneumococci, and staphylococci is a little less than that of adult serum. It falls still lower during the first months of life and does not equal the opsonic power of adult serum until about the second year.

2. That the phagocytic activity of the leukocytes of infants toward streptococci, pneumococci, and staphylococci follows a course similar to that of the opsonic indices. The leukocytes at birth are a little less active than adult leukocytes. Their activity diminishes considerably during the first months of life and does not reach that of adult leukocytes until about the third year.

3. The phagocytic power of the whole blood of infants drops

I Sour. Amer. Med. Assoc., 1910, 54, p. 682. 
decidedly during the first and second months of life and does not reach that of adult blood until about the third year.

4. During the first and second years of life the anti-infectious power of the blood as measured by the opsonic power of the serum and the phagocytic power of the leukocytes is far below that of adult blood. 